\title{
KAJIAN ARSITEKTUR KONTEMPORER DEKONSTRUKSI PADA BANGUNAN PERTUNJUKAN (Studi Kasus : Harbin Opera House, Tiongkok)
}

\author{
Guntur Ismawan', Ashadi ${ }^{2}$ \\ 'Universitas Muhammadiyah Jakarta, Program Studi Arsitektur \\ gunwaguno798@email.com \\ 2Universitas Muhammadiyah Jakarta, Program Studi Arsitektur \\ ashadi@ftumj.ac.id
}

\begin{tabular}{|c|c|c|}
\hline \multicolumn{2}{|c|}{ Informasi artikel } & ABSTRAK \\
\hline & \multirow{11}{*}{$\begin{array}{l}\text { Dengan perkembangan zaman yang terus berkembang, konsep hadir dan terus } \\
\text { bermunculan dari berbagai kalangan baik ilmuan ataupun dari sang arsitek } \\
\text { sendiri. Sehingga memunculkan konsep baru untuk memberikan penyegaran } \\
\text { terhadap konsep yang telah ada sebelumnya. Konsep tersebut yaitu } \\
\text { kontemporer dekonstruksi. Istilah kontemporer sama artinya dengan modern } \\
\text { yang kekinian, sehingga dapat dikatakan sebuah hal yang terbaharukan } \\
\text { Penerapan gaya kontemporer sendiri salah cara untuk membentuk suatu } \\
\text { identitas dan ciri yang baru melalui desain massa dan elemen visual. Sejalan } \\
\text { dengan itu, gaya-gaya arsitektur juga mulai tumbuh dan terus mengalam } \\
\text { perkembangan, lebih tepatnya dengan adanya gaya baru untuk menggantikan } \\
\text { gaya lama yang tampak membosankan. Gaya tersebut yaitu arsitektur } \\
\text { kontemporer dekontruksi, gaya ini muncul akibat kebosanan dan kejenuhan } \\
\text { yang ada pada gaya arsitektur modern. Dekonstruksi hadir sekitar pada tahun } \\
\text { 1970-an dibarengi oleh berbagai langgam arsitektur yang masuk pada masa } \\
\text { postmodernism atau langgam post-modern (Ghofur, 2010). Penelitian in } \\
\text { bermaksud untuk mendeskripsikan serta mengetahui penerapan Arsitektur } \\
\text { Kontemporer Dekonstruksi pada bangunan pertunjukan Harbin Opera House. }\end{array}$} \\
\hline artikel: & & \\
\hline Diterima & 13 Februari 2021 & \\
\hline Revisi & 29 Maret 2021 & \\
\hline Dipublikasikan & 30 Maret 2021 & \\
\hline \multirow{7}{*}{\multicolumn{2}{|c|}{$\begin{array}{l}\text { Kata kunci: } \\
\text { Arsitektur } \\
\text { Dekonstruksi } \\
\text { Harbin Opera House } \\
\text { Kontemporer } \\
\text { Teater }\end{array}$}} & \\
\hline & & \\
\hline & & \\
\hline & & \\
\hline & & \\
\hline & & \\
\hline & & ABSTRACT \\
\hline \multirow{5}{*}{\multicolumn{2}{|c|}{$\begin{array}{l}\text { Key word: } \\
\text { Architecture } \\
\text { Deconstruction } \\
\text { Harbin Opera House } \\
\text { Contemporary } \\
\text { Theatre }\end{array}$}} & $\begin{array}{l}\text { The times that continue to developing, the concept is present and continues to } \\
\text { emerge from various circles, both scientists and from the architect himself. So that }\end{array}$ \\
\hline & & it raises a new concept to provide a refresher on existing concepts. This concept is \\
\hline & & contemporary deconstruction. The term contemporary is the same as modern \\
\hline & & contemporary, so it can be said to be a renewable thing. The application of \\
\hline & & $\begin{array}{l}\text { through mass design and visual elements. In line with that, architectural styles } \\
\text { have also begun to grow and continue to experience development, more precisely } \\
\text { with the presence of new styles to replace the old styles that look boring. This style } \\
\text { is deconstructed architecture, this style arises from the boredom and boredom } \\
\text { that exists in modern architectural styles. Deconstruction was present around the } \\
1970 \text { accompanied by various architectural styles that entered the } \\
\text { postmodernism era or post-modern style (Ghofur, 2010). This study intends to } \\
\text { describe and determine the application of Contemporary Architecture with } \\
\text { Deconstruction in the Harbin Opera House. }\end{array}$ \\
\hline
\end{tabular}

\section{PENDAHULUAN}

Seni pertunjukan merupakan salah satu sebuah bentuk dari sekian banyak karya seni yang dipertontonkan disebuah tempat dan waktu tertentu untuk memuaskan kebutuhan masyarakat terhadap rekreasi, relaksasi atau media hiburan. Pertunjukan yang dimaksudkan sendiri terdiri dari 3 unsur yaitu adanya pelaku seni, penanggap dan penikmat seni itu sendiri (Yawan, Kedir dan Aspin, 2017). Dimana ketiga unsur tersebut saling keterkaitan satu sama lain demi memuaskan hasrat keinginan manusia. Dalam hal ini, pentingnya peran seni pertunjukan sangatlah dibutuhkan untuk dipertontonkan sebagai media penyampaian baik itu seni dan budaya. Namun seiring berkembangnya jaman, rasa kebosanan muncul dikalangan masyarakat terhadap seni pertunjukan di era-modern ini 
terus terjadi (Warso. E, 2017). Hal tersebut, berkaitan langsung dengan tingkat kebosanan terhadap geometri yang tercipta dari bangunan Gedung pertunjukan itu sendiri.

Dengan adanya hal tersebut, konsep baru perlu hadir untuk memendam rasa kebosanan terhadap bentuk yang itu-itu saja. Konsep yang dimaksudkan yaitu Kontemporer Dekonstruksi. Dalam arsitektur, penggunaan gaya kontemporer sendiri digunakan untuk membentuk suatu identitas dan memberikan ciri yang unik melalui desain elemen visual. Arsitektur kontemporer dapat diartikan sebagai aliran arsitektur yang mencerminkan kebebasan untuk berekspresi, memiliki keinginan untuk menampilkan sesuatu yang berbeda dari yang lainnya, dan merupakan aliran arsitektur yang baru atau dapat disebut sebagai penggabungan dari beberapa aliran arsitektur (Marscha A.A, et all, 2019). Sementara itu dekonstruksi merupakan gaya yang muncul akibat kebosanan dan kejenuhan yang ada pada gaya arsitektur terdahulu. Sehingga muncul pemahaman-pemahaman baru dalam konteks desain arsitektur yaitu dekontruksi itu sendiri. Dekonstruksi hadir sekitar pada tahun 1970-an dibarengi oleh berbagai langgam arsitektur yang masuk dalam postmodernism atau langgam post-modern. Bisa dikatakan adalah suatu pendekatan terhadap perancangan bangunan dengan mencoba melihat arsitektur dari segi bentuk dan menghadirkan hal yang baru (Reginaldo, 2017).

Konsep Arsitektur Dekonstruksi yang mulai lazim berkembang dan sudah menjadi gaya desain yang sangat menarik dan sudah banyak diterapkan pada bangunan di era modern sekarang ini (Anjarwulan dan Hamzah, 2019). Dekonstruksi/ dekonstruktivisme sendiri merupakan pengembangan konsep arsitektur yang lahir dari gaya arsitektur post-modern pada sekitar tahun akhir dekade 1980an (Martini dan Makainas, 2011). Karakter yang melekat dalam arsitektur dekontruksi yaitu konsepkonsep bentukan yang berbeda dan berlawanan dengan konsep bentukan pada umumnya. Methaphor dekonstruktif dilandasi pada konsep bentuk filosofi-anti yang menerapkan ekspresi-ekspresi yang berada diantara pemahaman bentuk geometri yang cenderung aneh dan tidak memiliki batasan (Dharma).

Untuk itu konsep arsitektur kontemporer dekonstruksi harus lebih diperkenankan lagi terhadap bangunan pertunjukan demi menciptakan bentuk bangunan yang baru dan tentunya menghilangkan rasa kebosanan. Salah satu gedung pertunjukan yang dinilai mengusung konsep arsitektur kontemporer dekonstruksi adalah Harbin Opera House di Tiongkok. Konsep arsitektur kontemporer dekonstruksi pada bangunan pertunjukan perlu dipelajari lebih lanjut agar konsep tersebut dapat ditularkan pada bangunan pertunjukan lainnya. Hal yang akan dikaji yaitu bagaimana penerapan arsitektur kontemporer pada bangunan Harbin Opera House serta aspek-aspek apa saja yang harus diterapkan pada bangunan.

\section{METODOLOGI}

Metodologi penelitian yang dilakukan yaitu menggunakan metode kualitatif deskriptif dengan pendekatan studi kasus. Metode deskriptif kualitatif merupakan metode dengan teknik penyajian secara deskripsi dapat berupa tulisan dan narasi yang diperkuat dengan daya dukung berupa gambar untuk memudahkan pembaca agar tidak salah mengansumsikan apa yang dinarasikan (Sugiyono, 2013). Sedangkan proses pengambilan data yang dilakukan melalui data sekunder, dikarenakan masa pandemi yang masih terus beredar dan tidak dimungkinkannya pengambilan data secara lansung (on site). Dan analisis yang dilakukan terhadap studi kasus yang dipilih, diperoleh dari pilihan dari berbagai literatur yang berkaitan terhadap studi kasus. 


\section{HASIL DAN PEMBAHASAN}

\section{Kompleksitas Bentuk Terhadap Bentuk Tidak Murni}

Merupakan hasil ide-ide antara penggabungan beberapa geometri perancangan awal sehingga menghasilkan perancangan yang bersifat kompleks. Kompleks dalam KBBI adalah suatu kesatuan yang terdiri dari beberapa bagian yang berbeda, mencerminkan sebuah bentukan yang saling mendukung dan berhubungan serta berketergantungan antara satu dengan yang lainnya (Siregar M, 2019). Yang dimaksudkan dalam bentuk ketidakmurnian ini adalah bentuk-bentuk geometris yang tidak dapat terukur dan tidak dapat didefinisikan, seperti lingkaran, bola, bujur sangkar, tabung, limas, dan sebagainya (Ashadi, 2019). Dimana bentukan yang dihasilkan akan memberikan kesan yang menakjubkan dan tidak biasa. Bentukan geometri mengalami dekonstruksi bentukan awal, dimana ada yang mengalami penambahan atau pengurangan dan lain-lain terhadap bentuk dasar geometri sebelumya. Jadi kompleksitas dari pada bentukan tidak murni ini merupakan penggabungan geometri yang berasal dari bentukan tidak murni menjadi satu kesatuan yang utuh, sehingga geometri tampak dinamis (Pujantara R, 2014).

Pada gambar analisis dibawah, bahwa bentukan geometri mengadopsi dua massa bangunan yang terlihat seperti terpisah. Namun jika dilihat lebih dalam lagi, ternyata antara massa bangunan utama dan massa bangunan kedua dihubungkan dengan sebuah ruang perantara/ penghubung bangunan. Antara massa bangunan satu dan dua memiliki bentukan yang sama, hanya satu hanya saja dilatakkan terpisah dan menghadap kearah yang berbeda.
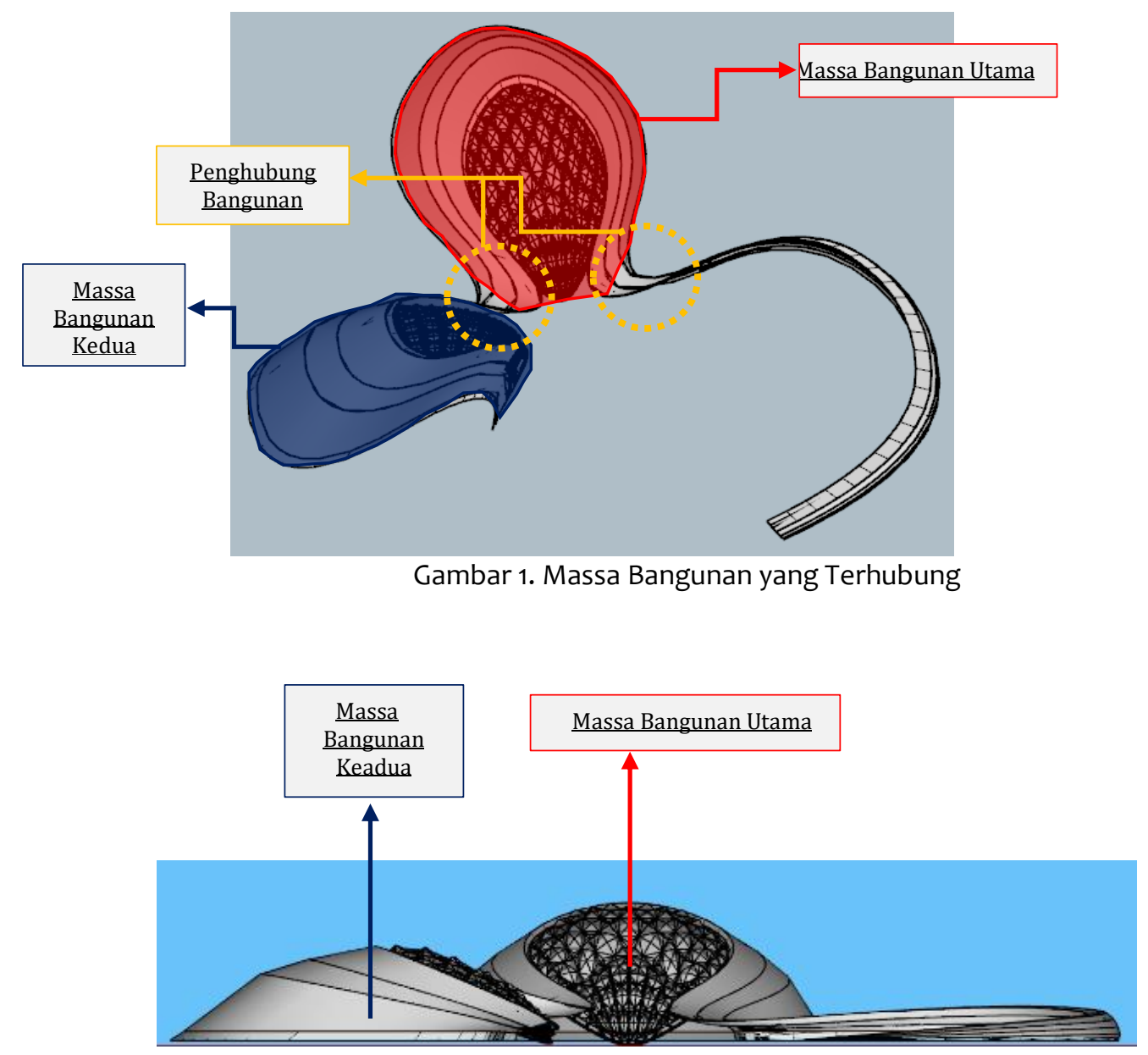

Gambar 2. Perletakan Massa Bangunan Yang Tergabung 
Geometri massa bangunan juga memberikan bentukan yang tidak dapat didefinisikan karena alur garis liuk-liuk memberikan kesan yang abstak. Hal ini dapat disimpulkan bahwa geometri bangunan menerapkan bentukan yang kompleksitas terhadap bentukan tidak murni, terlihat dari bagaimana perletakan massa yang terpisah dan arah hadap yang berbeda namun tidak menimbulkan perbedaan serta penggunaan dasar bentukan yang tidak murni.

\section{Bentukan Metafora dengan Penggunaan Ornamen}

Metafora arsitektur merupakan salah satu prinsip dalam desain Arsitektur dekonstruktivis. Metafora ini jika diartikan sebuah kata yang mengartikan kedalam arti yang bukan sebenarnya, melainkan sebagai lukisan yang berdasarkan persamaan atau perbandingan (Ashadi, 2019). Dimana menyerupai seperti sebuah bentukan yang ditirunya. Prinsip metaphor ini diwujudkan untuk memenuhi harapan atau sebuah pesan yang ingin disampaikan oleh perancang terhadap orang yang menikmati (Sinadia S \& Erdiono, 2011).

Prinsip metafora menginterpresentasikan sebuah hubungan antara benda yang dihubungkan dengan bentukan yang bersifat abstrak daripada nyata serta mengidentifikasikan pola hubungan geometri terhadap bentukan yang ditampilkan. Bentukan geometri metafora merupakan ekspresi percobaan yang ingin diperlihatkan dari seorang perancang seperti berkreasi dan bermain-main dengan imajinasinya untuk mewujudkan kedalam bentuk karya arsitektur. Metafora arsitektur mendorong timbulnya berbagai interprestasi dari pengamat yang melihat bangunan tersebut, dikarenakan pandangan setia orang akan berbeda-beda antara satu dengan satu lainnya (Ashadi, 2019).

Sedangkan penggunaan ornamen sendiri bertujuan untuk menambah nilai estetika dan penunjang bentukan methaphor. Ornamen merupakan penampilan bangunan yang mencerminkan kedinamisan yang dihasilkan dari penambahan berupa elemen tambahan pada fasad sehingga menciptakan nilai estetika yang lebih. Kedinamisan yang timbul dapat ditampilkan dari tampak yang ditampilkan pada suatu bangunan. Serta kedinamisan juga dapat tercermin dari penggunaan material ornamen yang memberikan estetika yang lebih terhadap kedinamisan bentuk (Ghozali dan Zuhri, 2020).
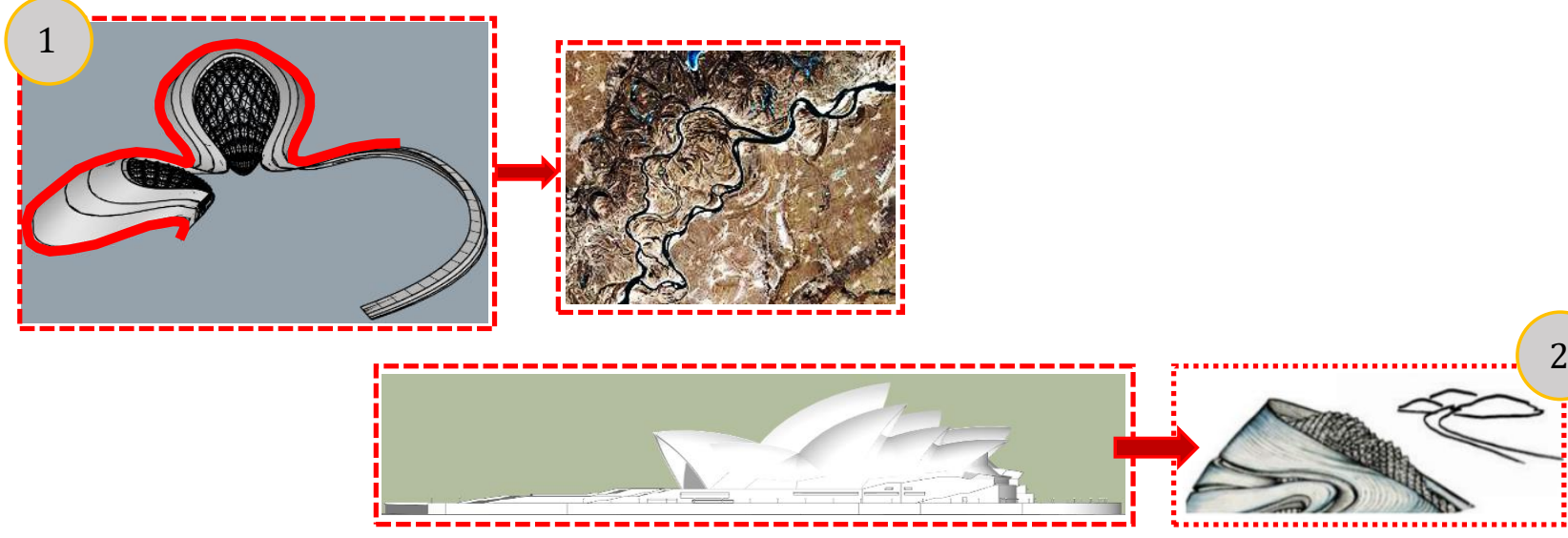

Gambar 3. Analisis Metaphor Harbin Opera House.

Pada gambar analisis diatas memperlihatkan bagaimana lengkungan bentukan bangunan yang memperlihatkan seperti sebuah bentukan yang mencair. Setelah diidentifikasi, ternyata bentukan lengkungan pada bangunan diinsiprasi dari bentuk aliran sungai yang mengaliri kota Harbin dan berada 
disekitar tapak tersebut. Sungai yang dimaksudkan yakni sungai Singhua, sungai yang memiliki nilai histori yang tinggi bagi kota Harbin sendirin (Gambar 3 poin 1). Dengan ini, dapat dikatakan bangunan harbin ini mengambil bentukan massa yang didapatkan dari inspirasi lingkungan bangunan ini didirikan.

Gambar diatas juga memperlihatkan bagaimana bentukan geometri yang dihasilkan oleh Harbin Opera House ini dihasilkan dari lingkungan sekitar lokasi bangunan ini didirikan, yakni kota Harbin, Tiongkok. Pada gambar 3 dipoin dua memperlihatkan bagaimana bentukan seperti sebuah pucuk pegunungan tertinggi. Imajinasi bentukan pegunungan ini, didapatkan dari imajinasi yang terinspirasi dari lokasi bangunan ini berdiri. Bangunan ini berdiri di kota Harbin yang notaben nya berdiri di sebuah pulau yang di sekitarnya terdapat sebuah pegunungan yang menjulang tinggi. Kondisi tersebut mengindikasikan bahwa massa geometri dari bangunan studi kasus Harbin Opera House menerapkan bentuk metaphor/ metafora. Bentukan tersebut terinspirasi/ menyerupai liukan dari sungai Singhua dan pegunungan di Kota Harbin.

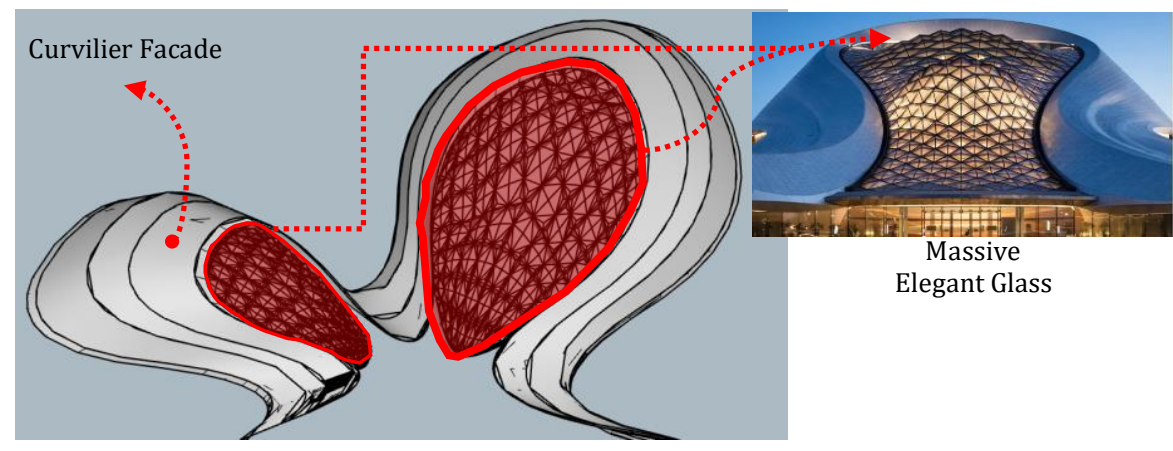

Gambar 4. Penggunaan material modern Harbin Opera House.

Pada analisis gambar diatas mengidentifikasi penggunaan material modern dan kekinian pada penerapan bangunan ini, terutama pada fasade penutup bangunan ini. Bangunan ini menggunakan ornament yang dikenal sebagai massiv elegant design yang diterapkan/ dipasangkan dicelah tengah bangunan Harbin Opera ini. Material tersebut selain digunakan sebagai ornamen namun dapat menyerap suhu diluar bangunan, karena suhu dikota Harbin sendiri dapat dikatakan cukup ektrim pada musim salju tiba. Selain menyerap suhu, glass tersebut juga berfungsi sebagai sumber masuknya pencahayaan alami disiang hari. Berdasarkan identifikasi analisis yang dilakukan, dapat dikatakan bahwa studi kasus ketiga ini menerapkan prinsip memiliki estetika dan ornamen dalam penerapan elemen bangunan nya. Sehingga tercipta nilai estetika yang tinggi dan penggunaan elemen ornamen untuk menambah daya tarik dan adaptasi suhu dengan keadaan lingkungan tersebut.

\section{Fluide (Mencair)}

Selanjutnya adalah prinsip fluide atau biasa disebut mencair. Cair ini merupakan bentuk yang dinamis dan menampilakan bentukan yang tampak bergerak. Dalam artian, prinsip cair ini menampilkan suatu geometri yang dinamis dan bergerak dalam segi perwujudan geometri massa bangunan maupun penggunaan elemen-elemen penunjang pada bangunannya (Ashadi, 2019). Geometri yang tercipta memperlihatkan bentuk-bentuk lengkungan yang halus dan membentuk sebuah garis yang menerus seolah bidang tersebut mengalir pada satu poros/ jalur yang sama. Bidang yang seolah- olah mengalir tersebut merupakan dikenal dengan sebutan curvilier facade. Penggunaan teknologi tersebut diterapkan untuk melapisi keseluruhan dari tampak bangunan ini untuk 
menciptakan bentukan yang seolah-olah mengalir (Adnan F \& Yunus, 2012). Kondisi tersebut mengindikasikan bahwa studi kasus ini menerapkan bentukan yang fluide/ mencair pada tampak ataupun geometri bangunan Harbin Opera House.

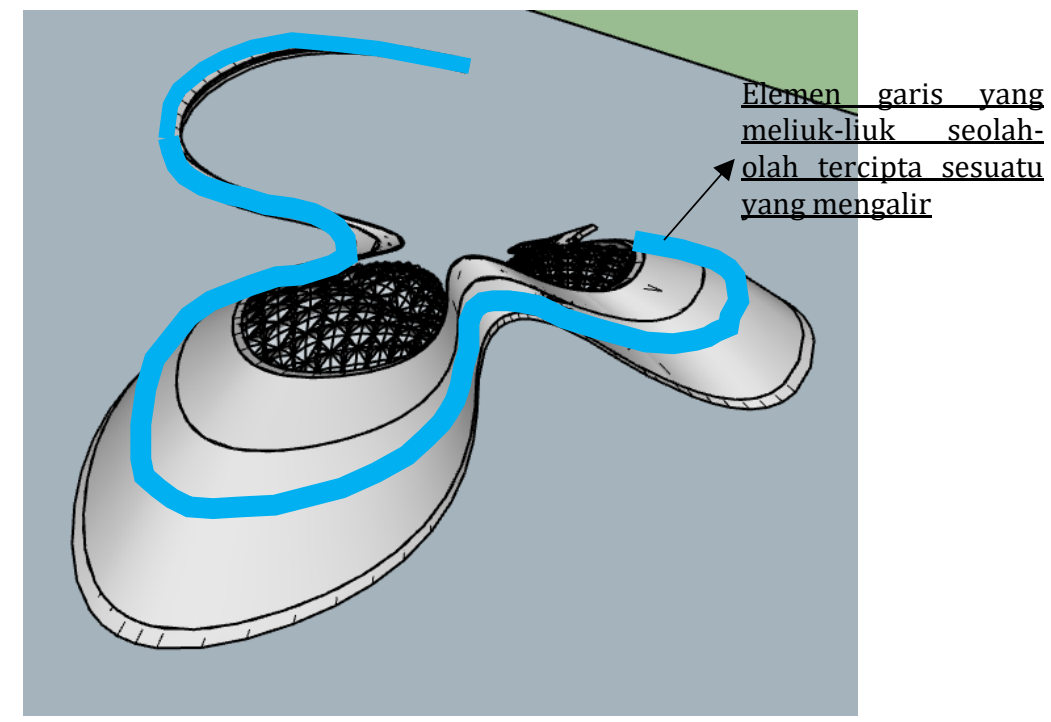

Gambar 5. Perspektif Harbin Opera House.

Jika dilihat dari perspektif bangunan Teater Jakarta, ditemukan nya elemen garis yang membentuk garis yang berliuk-liuk seperti sebuah garis yang mengalir dan mengindikasikan seolaholah bangunan mengalir seperti air. Hal tersebut mengindikasikan bahwa bentuk bangunan menerapkan bentukan yang fluide/ mencair baik pada tampak ataupun geometri bangunan Teater Jakarta.

\section{Distortion (Distorsi)}

Dalam kamus Besar Bahasa Indonesia, berasal dari kata distorsi yang dapat diartikan pemutarbalikan suatu fakta, aturan, dan sebagainya. Secara garis besar, distorsi bentuk ini adalah sebuah penyimpangan yang dihasilkan dari sebuah bentuk yang seharusnya terjadi, baik itu besar maupun kecil. Peyimpangan ini diterapkan baik itu secara horizontal maupun vertikal pada geometri bangunan (Ashadi, 2019).

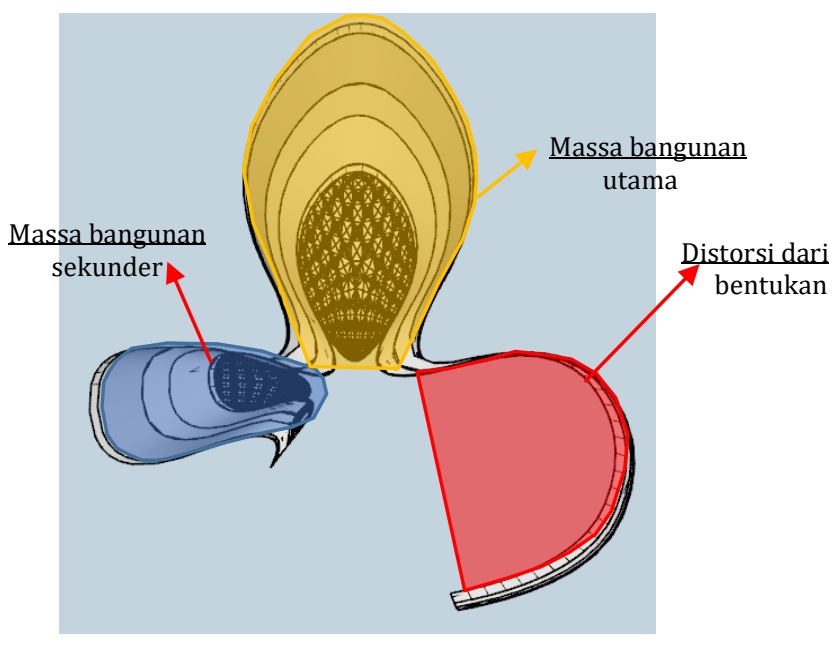

Gambar 6. Blok Plan Harbin Opera House. 
Pada massa bangunan Harbin Opera House terdiri dari dua massa bangunan. Massa tersebut tergabung menjadi satu kesatuan berkat adanya penghubung untuk menyatukan antar massa bangunan satu dan dua. Namun disisi kanan terlihat adanya suatu bentukan yang menyimpang dibandingkan bentukan yang massa lainnya (ditandai dengan warna merah). Bentuk tersebut difungsikan sebagai selasar untuk menyatukan antara massa bangunan utama dengan bangunan sekunder.

Hal tersebut dikatakan menyimpang karena bentukan tersebut mengalami distorsi dari bentukan murni. Nampak sekali terlihat tidak sempurna, seperti menampakkan suatu bentukan yang tidak utuh. Kondisi tersebut dapat dikatakan bahwa bangunan studi kasus Harbin Opera House menerapkan bentukan massa yang menyimpang dengan mendistorsi geometri baik secara vertikal dan horizontal. Berikut perspektif bangunan yang menampilkan bagaimana adanya distorsi geometri.

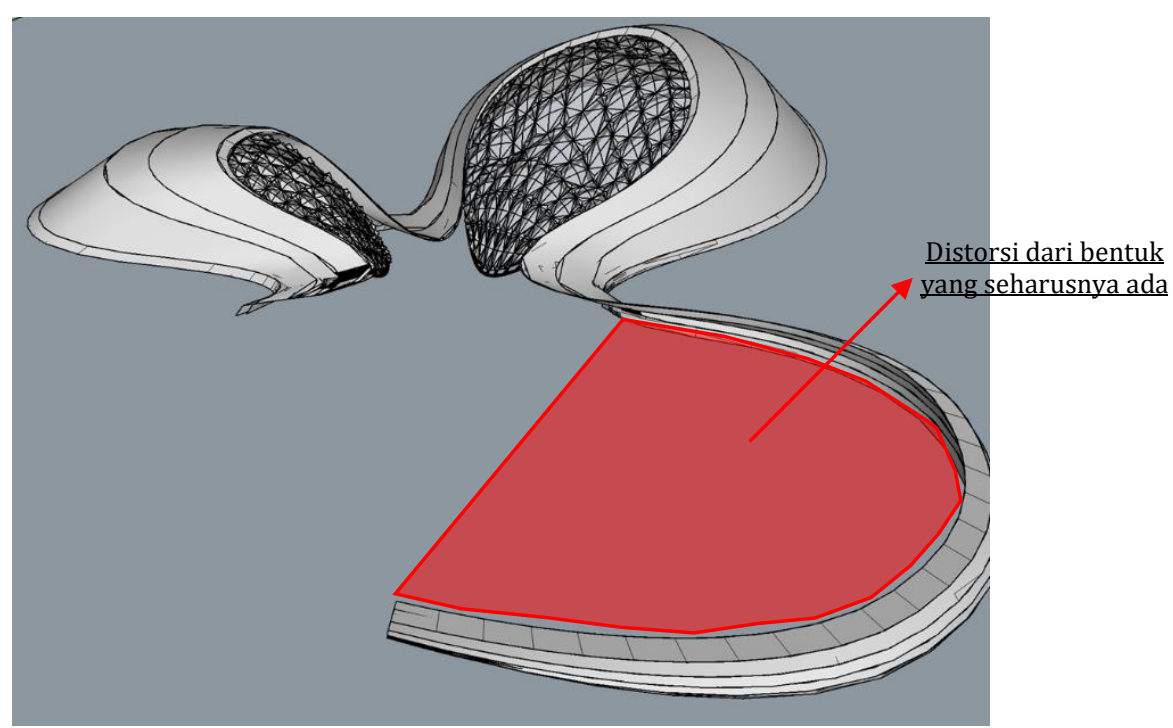

Gambar 7. Distorsi Bentuk.

\section{In Context (Berkonteks dengan Lingkungan)}

Menurut Kamus Besar Bahasa Indonesia, istilah konteks memiliki arti situasi yang ada hubungannya dengan suatu kejadian. Dalam bidang arsitektur, istilah ini mulai dikenal menjadi prinsip kontekstualisme dalam konsep arsitektur, yang artinya sama dengan pengakuan bahwa gaya arsitektur suatu bangunan selalu merupakan bagian fragmental dari sebuah gaya arsitektur yang lebih luas. Dalam hal ini gaya mengikuti konteks dengan lingkungan disekitar baik bentuk ataupun geometr (Ashadi, 2019). 


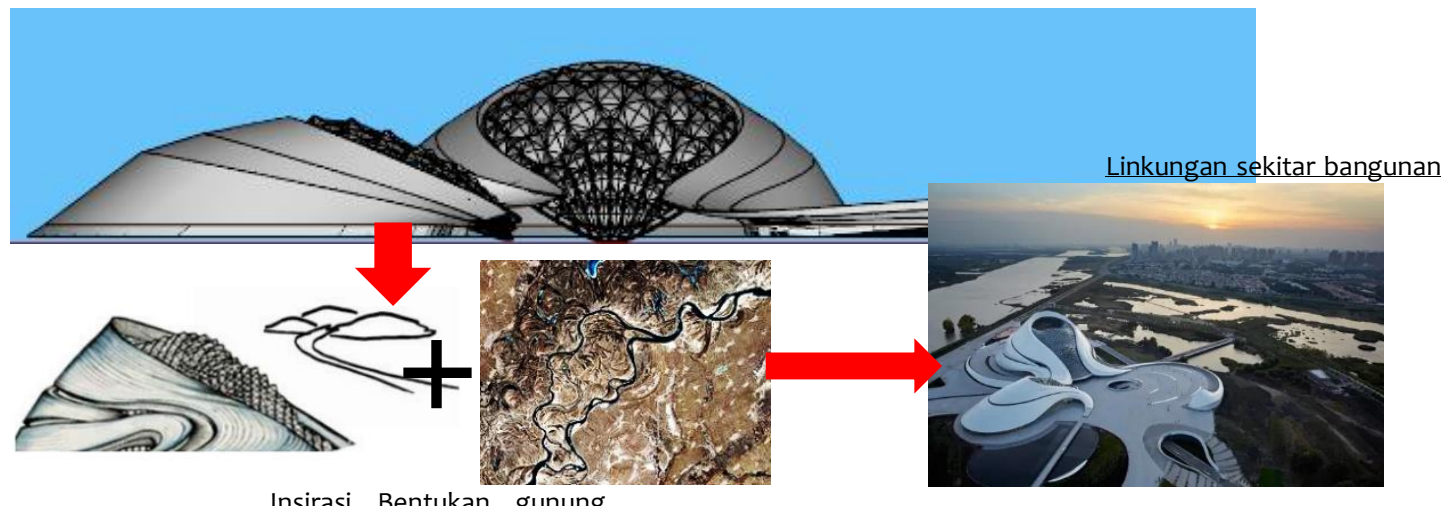

Gambar 8. Analisis Kontekstual Teater Jakarta.

Konsep bentukan massa bangunan Harbin sendiri merupakan inspirasi dari bentukan geografis lingkungan disekitar bangunan ini didirikan. Insirasi tersebut berasal dari Sungai Singhua jika dilihat dari tampak blok plan dan insiprasi bentuk pegunungan yang ada disekitar kota Harbin jika dilihat dari sisi tampaknya. Sehingga dapat dikatakan, antara konsep massa geometri terkoneksi dengan lingkungan yang ada disekitar, penerapan kontekstual terhadap massa bangunan sangat baik.

\section{PENUTUP}

Penerapan terhadap arsitektur kontemporer dekonstruksi pada bangunan pertunjukan dapat dilihat berdasarkan aspek-aspek penting pembentuk arsitektur kontemporer dekonstruksi, meliputi kompleksitas bentuk terhadap bentuk murni, bentuk metafora dengan penggunaan ornament, fluide (mencair), distortion (distorsi) dan in context (berkonteks dengan lingkungan). Seluruh komponen tersebut dapat mencerminkan karakter utama arsitektur kontemporer dekonstruksi melalui perwujudan bangunan yang dibangun. Penerapan kompleksitas bentuk terhadap bentuk murni diterapkan pada bentukan geometri yang tercipta dengan menerapkan beberapa geometri tidak murni serta terdiri dari beberapa geometri yang berbeda namun disatukan menjadi satu kesatuan yang utuh, sehingga terlihat dinamis dan tercipta kompleksitas yang baik.

Prinsip bentuk metafora dengan penggunaan ornamen diterapkan pada bangunan dengan menerapkan cara memperlihatkan bentukan geometri yang menyerupai benda hidup ataupun mati serta penggunaan ornamen pada bagian fasad nya demi bertambahnya nilai estetika pada bangunan lebih menarik dan terlihat dinamis. Untuk prinsip fluide (mencair) diterapkan pada bangunan pertunjukan pada massa bangunan yang tercipta dengan membuat bentukan geometri yang meliukliuk selayaknya seperti bentukan yang mencair pada elemen fasad bangunan nya. Selanjutnya untuk prinsip distortion (distorsi) diterapkan pada geometri massa bangunan pertunjukan dengan cara mendistorsi bentukan baik kearah vertikal maupun horizontal untuk memenuhi konsep bentukan yang diinginkan oleh perancang.

Yang terakhir prinsip in context (berkonteks dengan lingkungan) dengan cara mengkontekstualkan geometri dan penggunaan material yang menyesuaikan dengan lingkungan disekitar tapak bangunan didirikan. Sehingga dapat dikatakan, dalam mendesain dengan konsep arsitektur kontemporer dekonstruksi perlu mengetahui prinsip-prinsip utama yang sudah disebutkan sebelumnya. Dengan penerapan prinsip-prinsip terhadap geometri massa bangunan yang tercipta akan memberikan geometri massa yang baru dan akan berbeda dengan geometri massa bangunan pada umumnya. 


\section{DAFTAR PUSTAKA}

Adnan., F \& Yunus. (2012). The Influence of Curvilinear Architecture Forms on Environment Behaviour. Procedia Social and Behavioral Sciences 49. Hh. 341-349. doi:10.1016/j.sbspro.2012.07.032

Anjarwulan, S. dan Hamzah. (2019). Sains dan Teknologi Bangunan Dekonstruksi Dalam Karya Zaha Hadid. Jurnal Arsitektur Grid. Vol.1, Hh. 30-37.

Ashadi, 2019, Konsep Dekonstruksi Dalam Arsitektur, Arsitektur UMJ Press, Jakarta.

Dharma, Agus. Paradigma Konseptual Arsitektur Dekonstruksi. http://staffsite.gunadarma.ac.id/agus dh/.

Fajrin., H \& Kurniawan., R. (2018). Gedung Pertunjukan Musik Dengan Penekanan Arsitektur Kontemporer. Sigma Teknika. Vol.1, No.1, Hh. 49-60.

Fitri A, 2013, Perkembangan Arsitektur Dunia Arsitektur Selalu Berkembang Dari Masa ke Masa, Akses 1 Oktober 2020, http://perkembanganarsitekturdunia.blogspot.com/2013/01/arsitekturkontemporer.html.

Ghofur. (2010). Analisis Dekonstruksi Tokoh Takeshi dan Mitsusaburo dalam Novel Silent Cry karya KenzuboOe Perspektif Jacques Derrida. Jurnal Nuansa, Vol. 12, Hh. 34-43.

Ghozali, M dan Zuhri, S. (2020). Ekspresi Estetika dan Simbolik Pada Arsitektur Kontemporer Dengan Pendekatan Metafora. Jurnal Mahasiswa Arsitektur. Vol. 1, Hh 34-43

Marscha, AA., Nirawati \& Winarto. (2019). Penerapan Prinsip Arsitektur Kontemporer Dalam Perancangan Ruang Kreatif Di Surakarta. Jurnal Senthong. Hh. 257-266.

Martini, J., Makanias, I. (2011). Eksplorasi Terhadap Arsitektur Dekonstruksi. Media Matrasain. Vol.8, No.2, Hh. 69-81.

Pujantara., R. (2014). Struktur Beton Bertulang Dalam Perspektif Fleksibilitas Bentuk Dan Arsitektur Plastis Pada Rancangan Dekonstruksi. Jurnal Forum Bangunan. Vol. 12, Hh. 68-72.

Reginaldo., Ch. (2017). Metode Pendekatan Desain Menurut Henry Bergson Dan Gilbert Ryle Terhadap Arsitektur Dekonstruksi, Seminar Nasional Riset dan Teknologi Terapan. ISBN 978-602-50244-0-5, hh. 51-56.

Sinadia., S \& Erdiono. (2011). New Methaphor In Architecture (Metafora Baru/ Terkini Dalam Arsitektur). Media Matrasain. Vol.8, No.3, Hh. 121-132.

Siregar, M . (2019). Kritik Terhadap Teori Dekonstruksi Derrida', Jurnal of Urban Sociologi, Vol. 2 No.1, hh. 65-75.

Sugiyono. (2018). Metode Penelitian Kuantitatif, Kualitatif, Dan R Dan D. Bandung : CV. Alfabeta.

Warso., E. (2017). Apartemen Atlet Bulutangkis Kudus (Pendekatan Arsitektur Kontemporer), Universitas Muhammadiyah Surakarta.

Yawan, H., Kadir, I., \& Aspin. (2020). Penerapan Konsep Metafora Pada Pusat Pertunjukan Seni Di Kota Kendari. Jurnal Arsitektur Garis. Vol.5, Hh. 107-114.

Zubaidi., F. (2010). Telaah Konsep Frank O Gehry Dalam Rancangan Arsitektur. Jurnal Ruang. Vol.2, No.2, Hh. 59-71. 